\title{
Diagnostic problems in fetal visceral heterotaxy syndrome. Sonography vs. autopsy
}

\author{
Cezary Niszczotaa ${ }^{a}$ Adam Koleśnika ${ }^{a}$ Joanna Szymkiewicz-Dangel ${ }^{b}$ \\ a Department of Descriptive and Clinical Anatomy, Center of Biostructure Research, Medical University of Warsaw, Poland \\ ${ }^{b}$ Perinatology and Prenatal Cardiology Unit, II Chair of Obstetrics and Gynecology, Medical University of Warsaw, Poland
}

\section{ARTICLE INFO}

Article history:

Received: 20 April 2012

Received in revised form:

26 June 2012

Accepted: 24 July 2012

Available online: 2 August 2012

Keywords:

Aplenia

Atrial isomerism

Congenital heart defect

Fetal echocardiography

Heterotaxy syndrome

Polysplenia

\begin{abstract}
Introduction: Visceral heterotaxy syndromes (VHS) are defined as abnormalities of the determination of left-right symmetry, described as left or right atrial isomerism (LAI, RAI) [11]. Some cases do not follow classical patterns and may cause diagnostic problems. The aim of this study is to determine whether their features can be helpful or misleading in the diagnosis of VHS.

Material and methods: The study was based on 6 cases diagnosed sonographically and/or in autopsy. The results of examinations were re-evaluated and compared.

Results: Two of 6 fetuses were diagnosed to have right atrial isomerism (RAI), 3 presented left atrial isomerism (LAI) and one case was diagnosed as VHS. Cardiovascular anomalies comprised: abnormal systemic venous connections (6/6), partial anomalous pulmonary venous drainage (PAPVD) (2/6), complete atrioventricular septal defect (CAVSD) (2/6), ventricular left-hand pattern (2/6), ventriculo-arterial discordance (1/6), tricuspid atresia (1/6), mitral atresia (1/6) and tetralogy of Fallot (ToF) (1/6). Fetuses diagnosed as LAI presented complete heart block. In 2 cases of RAI and in 3 cases of LAl isomeric anatomy of the atrial appendages was observed. None of fetuses with LAI presented "polysplenia" and none of fetuses with RAI presented "asplenia". Lungs and main bronchi were isomeric in 3 cases of LAl and in no cases of RAl. One fetus with otocephaly presented atrial situs solitus and multiple cardiac anomalies, situs ambiguus of lungs and bronchi and situs solitus of the abdominal viscera.

Conclusions: There are characteristic features of left and right isomerism, and they may be present in various forms. In some cases extracardiac features of VHS can be seen only on autopsy.
\end{abstract}

(c) 2012, ČKS. Published by Elsevier Urban and Partner Sp. z o.o. All rights reserved.

\section{Introduction}

The word heterotaxy stems from Greek origin, with "heteros" meaning "other" and "taxis" meaning "arrangement" [1]. Heterotaxy syndromes are disorders that involve abnormal lateralization of the viscera, including thoracic and abdominal organs, as well as congenital cardiac malformations. Over the decades a lot of investigators described cases presenting features of visceral heterotaxy syndrome (VHS).
In 1955 Ivemark first published a study describing asplenia syndrome as "teratologic syndrome of visceral symmetry" associated with cono-truncal anomalies [2]. In 1962 Van Mierop and Wiglesworth proved that not only severe cardiac malformations exist with splenic anomalies, but also atypical lobation of lungs, state of the liver and partial situs inversus may also be observed [3]. Some authors, like Van Praagh, defended the concept of asplenia and polysplenia syndrome and denied the value of atrial situs evaluation [4-6]. Anderson and Becker suggested that morphology of atrial appendages but not

Address: Cezary Niszczota, Department of Descriptive and Clinical Anatomy, Center of Biostructure Research, Medical University of Warsaw, Chałubińskiego 5, Warsaw 02-004, Poland, e-mail: cniszczota@student.wum.edu.pl

DOI: $10.1016 /$ j.crvasa.2012.07.002 
entire atriums is relevant $[7,8]$. Uemura's study correlated morphology of atrial appendages with other cardiac defects characteristic of isomeric left and isomeric right atrial appendages, confirming Anderson's concept [9-11]. Thus, the nomenclature of VHS was established basing on morphology of atrial appendages [12]. However, there exist cases which do not follow the classical patterns described, and may cause diagnostic problems on prenatal as well as on post-mortem examination.

In this study we aimed to find common features of VHS on prenatal as well as on post-mortem subjects and to determine which of them can or cannot be helpful on ultrasound examination.

\section{Material and methods}

The study was based on 6 cases of VHS diagnosed on ultrasound and/or on post-mortem examination. Prenatal echocardiography is reliable for diagnosis of cardiac malformations and other extracardiac defects since early gestation (17 weeks of gestation) $[13,14]$. In all patients two-dimensional echocardiaphic images were obtained. In those views pulsewave Doppler and color Doppler were also performed. This technique was used to visualize the flow in ductus venosus and the umbilical vessels. M-mode technique was performed to verify cardiac rhythm. All examinations were performed on an Acuson Sequoia 512 imaging ultrasound system, using a 2-5 $\mathrm{MHz}$ transabdominal transducer in order to obtain the best resolution, depending on maternal state and gestational age. In all 6 cases the fetuses or newborns died soon after birth. Autopsy was performed according to the guidelines of sequential segmental analysis of the heart $[6,12,15]$. All the examinations consisted of two main parts: general evaluation of visceral situs and the morphology of the lungs and the main bronchi, the state of the liver and spleen, and the precise anatomy of the heart. The results of ultrasound and postmortem examinations were re-evaluated and compared.

\section{Results}

In four of six cases the reason of admission for prenatal echocardiography was the abnormal imaging of the heart on ultrasound by the obstetrician. In one case it was caused by increased nuchal translucency (NT) on the first trimester sonography. One patient was investigated by cardiologist because of her diabetes mellitus.

Three of six cases were described as a left atrial isomerism on ultrasound examination. The diagnosis was based on morphological features of atria (Fig. 1), the existence of an interruption of the hepatic portion of the inferior vena cava with the azygos vein continuation and complete heart block with association to congenital heart disease. One patient with a fetal diagnosis of VHS had balanced atrioventricular septal defect and pulmonary trunk atresia, the second one had ventricular septal defect and transposition of great arteries, and the third had a hypoplastic right ventricle and pulmonary trunk atresia. The autopsy confirmed diagnosis of 3 cases of left atrial isomerism (Fig. 2 and Fig. 3). None of them

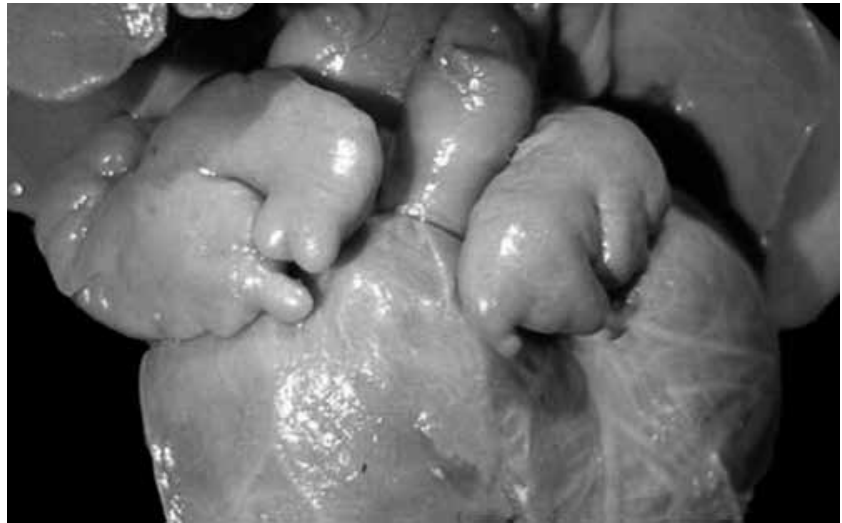

Fig. 1 - Case 3 - isomeric left atrial appendages (LAA - left atrial appendage, RAA - right atrial appendage).

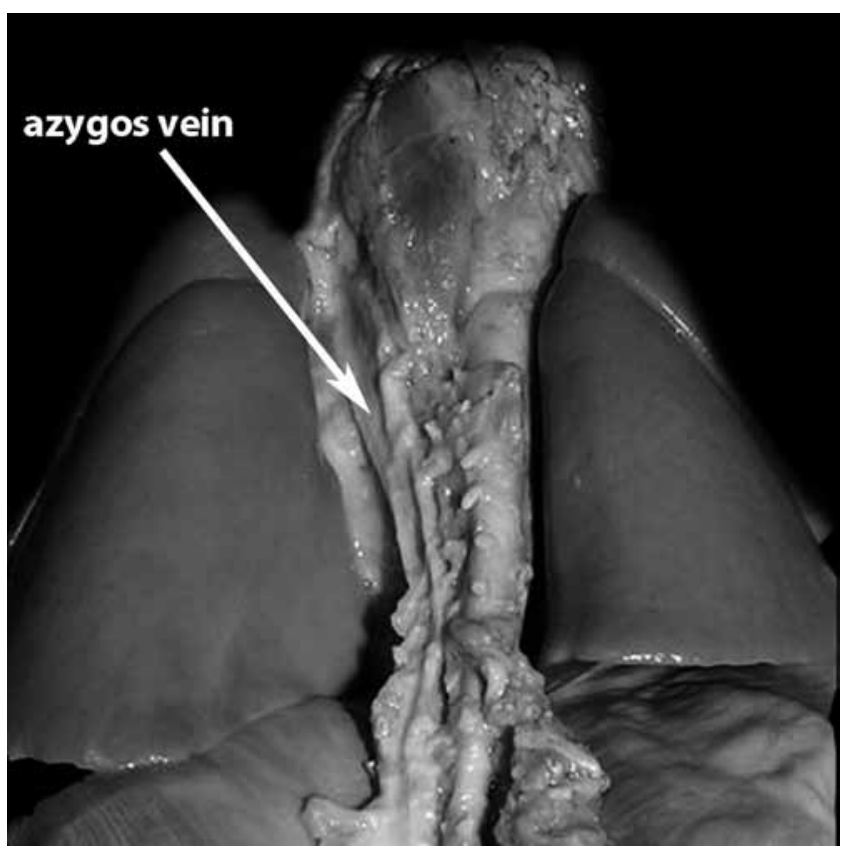

Fig. 2 - Case 2 - interrupted inferior vena cava with dilated azygos vein continuation (arrow). Bilateral bilobar lungs.

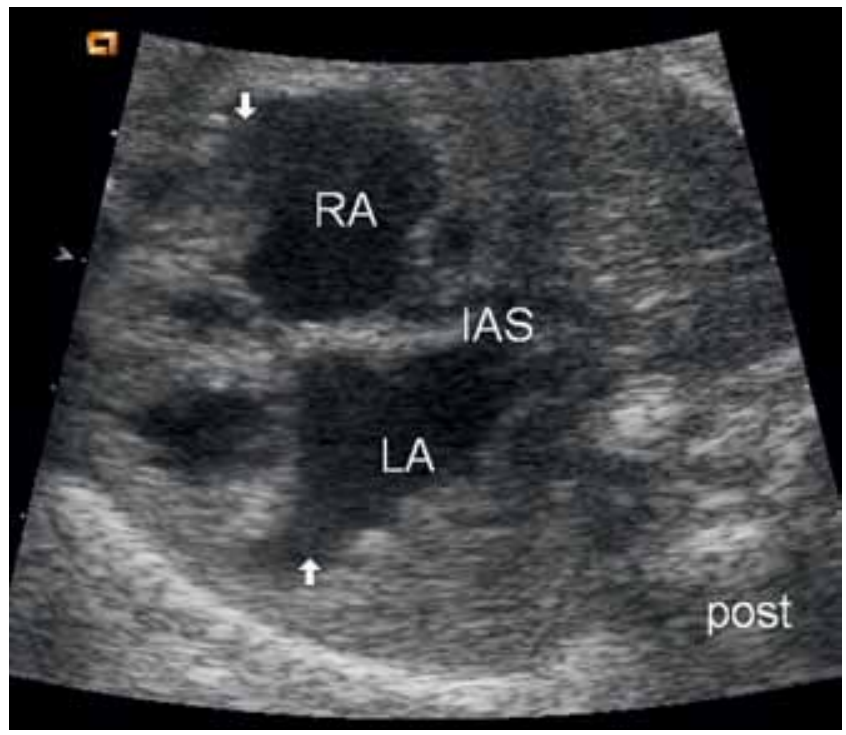

Fig. 3 - Case 5 - four-chamber view. Isomeric right atrial appendages (arrows). 


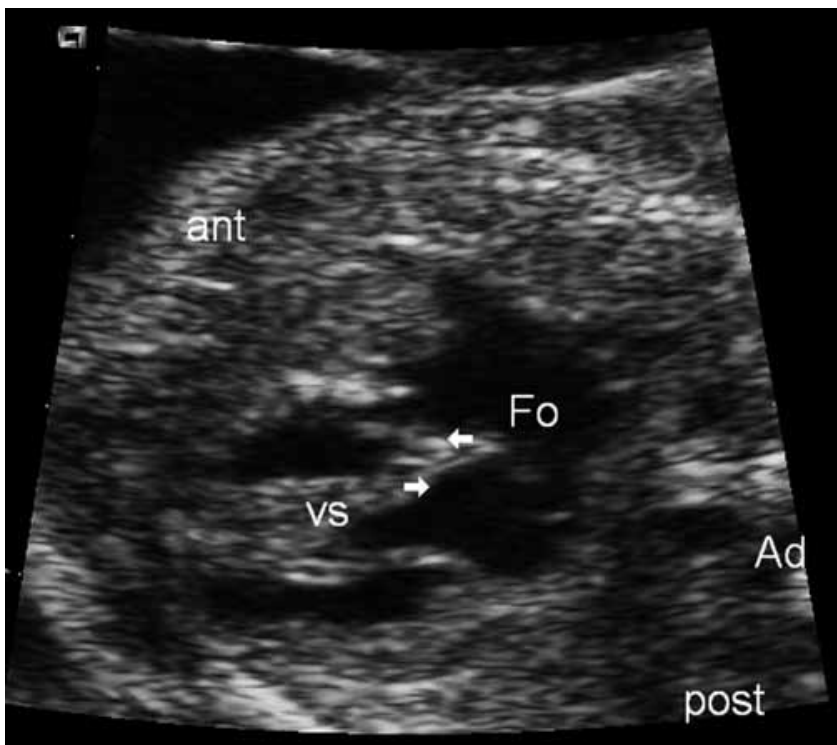

Fig. 4 - Case 5 - inversion of ventricles. Attachments of AV valves (arrows). VS - ventricular septum, Fo - foramen ovale.

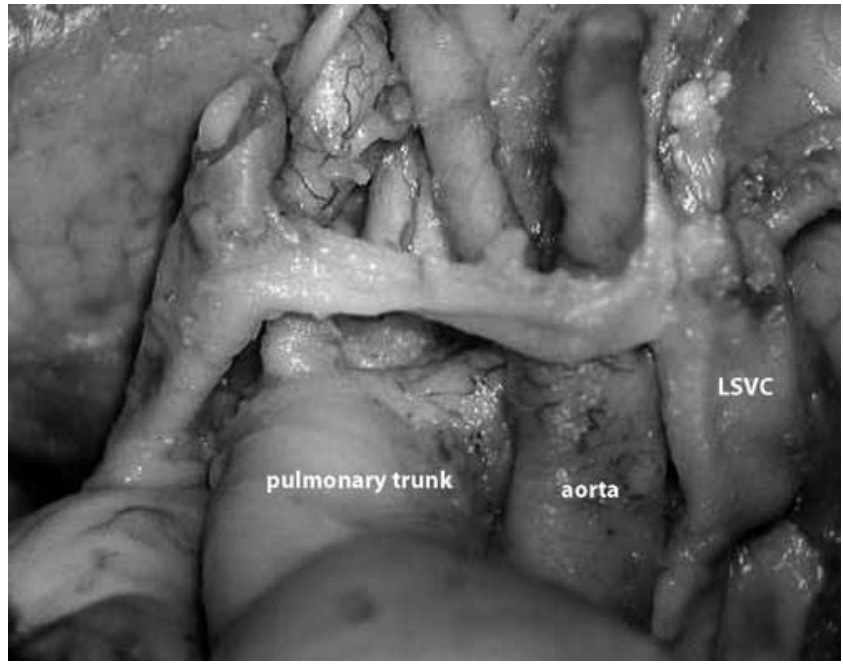

Fig. 5 - Case 5 - left superior vena cava (LSVC). Both superior caval veins connected by brachiocephalic vein (RSVC - right superior vena cava).

presented polysplenia and in one case the spleen was hypoplastic.

One case of right atrial isomerism was diagnosed in utero as visceral heterotaxy syndrome and associated pulmonary trunk atresia with intact interventricular septum; it was described also on postnatal echocardiography. After birth sonography revealed RAI (Fig. 4), inversion of ventricles (Fig. 5), aortic valve atresia and partial anomalous of the drainage pulmonary veins (right pulmonary veins return to the right atrium). The autopsy confirmed diagnosis and additionally revealed the other features of RAl: absence of coronary sinus and an accessory left superior vena cava (Fig. 6). Two cases were not classified as visceral heterotaxy syndromes on ultrasound.

In one case diagnosed prenatally as tetralogy of Fallot, post-mortem examination revealed isomeric right atrial appendages (Fig. 7), absent coronary sinus, atypical lobation of lungs and asplenia.

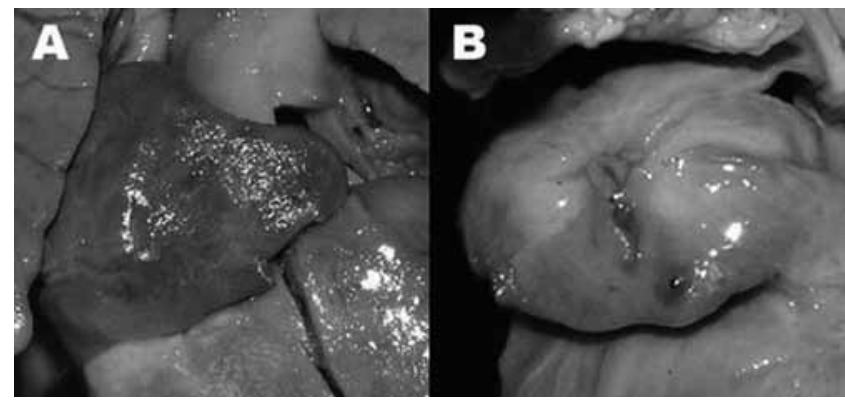

Fig. 6 - Case 6 - isomeric right atrial appendages.

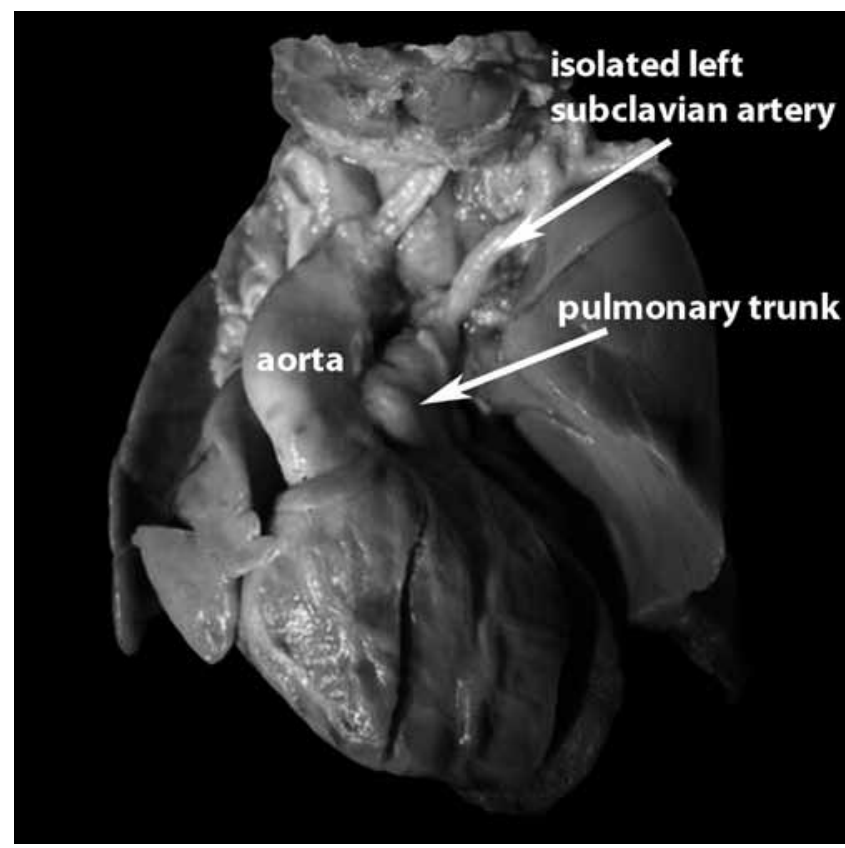

Fig. 7 - Case 4 - isolation of left subclavian artery (arrow). PT - pulmonary trunk, Ao - aorta.

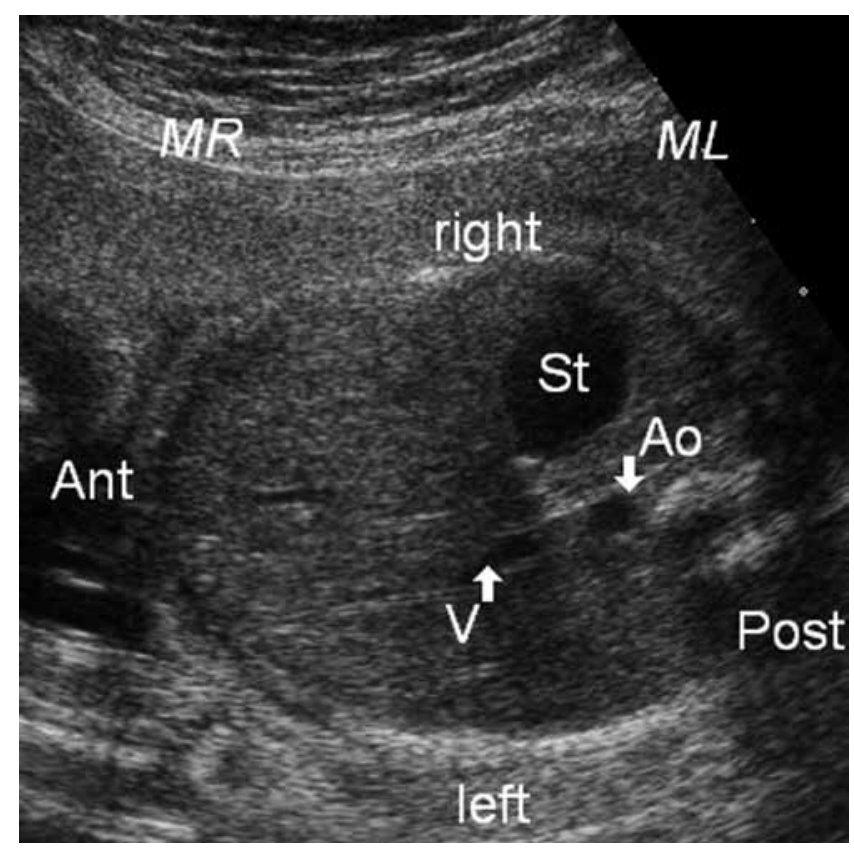

Fig. 8 - Case 5 - Aorta and stomach on the right side (MR/ML mother right/left, St - stomach). 
The last fetus was diagnosed as a left atrial isomerism only because of isomeric left lungs and main bronchi on post-mortem examination. It presented phenotypic features of otocephaly, which is known to be associated with mutation of the sonic hedgehog $(\mathrm{SHH})$ gene and isomeric left atrial appendages [16-18]. Autopsy also revealed an isolation of the left subclavian artery, which originates from pulmonary trunk (Fig. 8). The vertebral artery on this side was remarkably dilated suggesting a collateral circulation via circle of Willis.

The results of examinations are summarized in Table 1.

\section{Discussion}

Over the years the patients collected in the groups of heterotaxy syndrome have been described in terms of 'asplenia' or 'polysplenia' $[12,19,20]$. During this period Van Mierop and associates had emphasized the tendency toward isomerism in these syndromes of the thoracic organs [21]. Our cases confirmed that the state of the spleen could not divide the overall group of heterotaxy into the entities of right and left isomerism. Nowadays, the terms 'asplenia' and 'polysplenia' seem to be only traditional concepts. It is significant for clinicians that the evaluation of the function of the spleen is obligatory in children with heterotaxy syndromes, but it is only helpful, not crucial in diagnosis.

According to Uemura's study the diagnosis of VHS should be based mostly on morphology of the atriums [22]. Other malformations are described as associated.

Well-recognized features of the morphological left atrium are:

1. Tubular appendage having a narrow junction with the rest of the atrium,

2. smooth surface of the pulmonary venous component.

Most characteristic features of the right atrium are:

- Triangular appendage having a broad junction with the venous component of the atrium,

- prominent pectinate muscles within the appendage, extending to the posterior wall of the atrium and attaching to the terminal crest.

\section{Table 1 - Cases of VHS included into the study.}

\begin{tabular}{|c|c|c|c|c|c|c|c|c|c|}
\hline \multirow{2}{*}{ No. } & \multirow{2}{*}{$\begin{array}{c}\text { GA } \\
\text { (weeks) }\end{array}$} & \multicolumn{4}{|c|}{ Fetal echocardiography } & \multicolumn{4}{|c|}{ Autopsy } \\
\hline & & Heart & NIHF & CVS & Other US findings & Viscera & Heart & Lungs & Other \\
\hline 1 & 24 & $\begin{array}{l}\text { Isomeric } \\
\text { left atrial } \\
\text { appendages, } \\
\text { CHB, VSD, TGA }\end{array}$ & 1 & $\begin{array}{l}\text { Interrupted } \\
\text { IVC }\end{array}$ & - & $\begin{array}{l}\text { Liver in the } \\
\text { middle }\end{array}$ & $\begin{array}{l}\text { Isomeric left atrial } \\
\text { appendages, VSD, } \\
\text { DILV, ASD II }\end{array}$ & $\begin{array}{l}\text { Bilaterally } \\
\text { 2-lobed lungs } \\
\text { and long main } \\
\text { bronchi }\end{array}$ & $\begin{array}{l}\text { Interrupted } \\
\text { IVC }\end{array}$ \\
\hline 2 & 17 & $\begin{array}{l}\text { Isomeric } \\
\text { left atrial } \\
\text { appendages, } \\
\text { CHB, PT } \\
\text { stenosis }\end{array}$ & 1 & $\begin{array}{l}\text { Interrupted } \\
\text { IVC }\end{array}$ & - & $\begin{array}{l}\text { Liver in the } \\
\text { middle }\end{array}$ & $\begin{array}{l}\text { Isomeric left atrial } \\
\text { appendages, } \\
\text { interrupted, tricuspid } \\
\text { atresia, } \\
\text { PT stenosis, } \\
\text { non-compacted } \\
\text { myocardium of the } \\
\text { left ventricle }\end{array}$ & $\begin{array}{l}\text { Bilaterally } \\
\text { 2-lobed lungs } \\
\text { and long main } \\
\text { bronchi }\end{array}$ & $\begin{array}{l}\text { Interrupted } \\
\text { IVC }\end{array}$ \\
\hline 3 & 22 & $\begin{array}{l}\text { Isomeric } \\
\text { left atrial } \\
\text { appendages, } \\
\text { CHB, AVSD, PT } \\
\text { atresia }\end{array}$ & 0 & $\begin{array}{l}\text { Interrupted } \\
\text { IVC }\end{array}$ & - & - & $\begin{array}{l}\text { Isomeric left atrial } \\
\text { appendages, } \\
\text { AVSD, ASD II }\end{array}$ & $\begin{array}{l}\text { Bilaterally } \\
\text { 2-lobed lungs } \\
\text { and long main } \\
\text { bronchi }\end{array}$ & $\begin{array}{l}\text { Interrupted } \\
\text { IVC }\end{array}$ \\
\hline 4 & 30 & $\begin{array}{l}\text { AVSD, DORV, } \\
\text { PT stenosis }\end{array}$ & 0 & - & $\begin{array}{l}\text { Stomach invisible, } \\
\text { polyhydramnion } \\
\text { (suspition of } \\
\text { esophageal atresia) }\end{array}$ & - & $\begin{array}{l}\text { Mitral atresia, } \\
\text { absence of left atrial } \\
\text { appendage, absence } \\
\text { of DA, left subclavian } \\
\text { artery originating } \\
\text { from PT, straddling } \\
\text { and overriding TV }\end{array}$ & $\begin{array}{l}\text { Bilaterally } \\
\text { 2-lobed lungs } \\
\text { and long the } \\
\text { main bronchi }\end{array}$ & Otocephaly \\
\hline 5 & 27 & $\begin{array}{l}\text { Visceral } \\
\text { heterotaxy } \\
\text { syndrome, } \\
\text { PT atresia with } \\
\text { intact IVS }\end{array}$ & 0 & - & - & $\begin{array}{l}\text { Stomach } \\
\text { and spleen } \\
\text { on the right } \\
\text { side }\end{array}$ & $\begin{array}{l}\text { RAl, inversion } \\
\text { of ventricles, AoV } \\
\text { atresia, absent CS, } \\
\text { LSVC }\end{array}$ & - & - \\
\hline 6 & 25 & $\begin{array}{l}\text { ToF, VSD, } \\
\text { hypoplastic } \\
\text { PT }\end{array}$ & 0 & - & - & Asplenia & $\begin{array}{l}\text { Isomeric right atrial } \\
\text { appendages, absent } \\
\text { CS, ASD II, ToF }\end{array}$ & $\begin{array}{l}\text { Atypical } \\
\text { lobation } \\
\text { of lungs }\end{array}$ & - \\
\hline
\end{tabular}

AoV - aortic valve; ASD II - atrial septal defect (ostium secundum type); AVSD - atrioventricular septal defect; CHB - complete heart block; CS - coronary sinus; CVS - cardiovascular system; DA - ductus arteriosus; DILV - double inlet left ventricle; DORV - double-outlet right ventricle; GA - gestational age; IVC - inferior vena cava; LAI - left atrial isomerism; LSVC - left superior vena cava; NIHF - non-immune hydrops fetalis; PT - pulmonary trunk; RAI - right atrial isomerism; TGA - transposition of great arteries; ToF - tetralogy of Fallot; VSD - ventricular septal defect. 
As we can see there are many features beyond the anatomy of the atriums that indicate whether we have right or left atrial isomerism.

Many investigators and experiences reveal that there are some evident features of left and right atrial isomerism, which are likely to be used in ultrasound. If both interrupted inferior vena cava and complete heart block are observed, we can almost be sure that there is a LAI $[13,23,24]$. In the longitudinal view the azygos vein and aorta are seen side by side. In these cases color Doppler can be helpful to visualize the flow in both vessels in opposite direction. Morphology of atrial appendages could be helpful and diagnostic in some cases. The features of LAl do not indicate a lethal character of defect. Nevertheless, third degree heart block may cause acute heart failure, fetal hydrops or intrauterine death. According to literature, complete heart block can be observed in $15-50 \%$ cases of LAI [25]. So that, we can deduce, there is a significant discrepancy between the results of different groups. Moreover, we are not able to establish, how many fetuses with complete heart block die in utero with no diagnosis in pregnancy and in autopsy.

The diagnosis of right atrial isomerism is much more difficult than left. Absence of the coronary sinus and bilateral superior vena cava are common, but not constant features of RAI [24]. Total anomalous pulmonary veins drainage is observed more often in patients with RAl than in those with LAI. The morphology of atrial appendages is helpful as well, however, on prenatal sonography we may suspect VHS not only thanks to classical features of heterotaxy. There are some markers carrying a prognosis of these malformations. The conotruncal anomalies (DORV, TGA, TOF, pulmonary stenosis or atresia etc.) are not usually seen in association with AVSD [26,27]. When both are seen together, heterotaxy syndrome should be suspected.

Genetic health care and testing are really important in the setting of VHS. There are many studies to indicate that heterotaxy syndromes can be caused by single gene mutations. VHS may arise from abnormal left-right embryonic patterning with abnormal arrangement of the cardiac chambers, great arteries, lungs and abdominal organs. It may be caused by mutations in genes that control early left-right patterning. Genes implicated in VHS iclude: ZIC3, LEFTYA, CRYPTIC and ACVR2B [28-31]. Also described large families showing an X-linked form of heterotaxy [32]. Analysis of the $X$ chromosome revealed the disease locus to be Xq24-27.1. The possibility to assess human genetic predisposition for VHS is increasing rapidly. It is an important aspect of genetic counseling for families where there have been cases of VHS. Unfortunately, multiplicity of the mutations in cases of heterotaxy syndromes makes troubles in everyday practice. None of patient from our study was genetically tested, because of high cost of the procedure and uncertain results.

There are some characteristic features of right and left atrial isomerism, but these may be presented in various forms, therefore simplified associations may be misleading. Prenatal diagnosis of VHS is based mostly on typical morphological and physiological features. As we can observe in this study as well as in other ones, it is easier to diagnose LAI rather than RAI. LAI can be recognized in cases with an interrupted inferior vena cava and complete heart block. Some atypical cases of VHS cannot be classified as LAI or RAI. In some cases the extracardiac malformations of VHS may be seen strictly upon autopsy examination.

\section{Refere nces}

[1] B. Ferdman, L. States, J.W. Gaynor, et al., Abnormalities of intestinal rotation in patients with congenital heart disease and heterotaxy syndrome, Congenital Heart Disease 2 (2007) $12-18$.

[2] B.I. Ivemark, Implications of agenesis of the spleen on the pathogenesis of cono-truncus anomalies in childhood, Acta Paediatrica Scandinavica 44 (Suppl. 104) (1955) 1-110.

[3] L.H. Van Mierop, F.W.Wiglesworth, Isomerism of the cardiac atria in the asplenia syndrome, Laboratory Investigation 11 (1962) 1303-1315.

[4] R. Van Praagh, S. Van Praagh, Atrial isomerism in the heterotaxy syndromes with asplenia, or polysplenia, or normally formed spleen: an erroneous concept, American Journal of Cardiology 66 (1990) 1504-1506.

[5] S. Van Praagh, F. Santini, S.P. Sanders, Cardiac malposition with special emphasis on visceral heterotaxy (asplenia and polysplenia syndromes), in: D.C. Fyler (Ed.), Nadas' Pediatric Cardiology. Hanley and Belfus, Philadelphia, 1992, pp. 589-608.

[6] S. Van Praagh, J. Kreutzer, L. Alday, R. Van Praagh, Systemic and pulmonary venous connections in visceral heterotaxy with emphasis on the diagnosis of the atrial situs: a study of 109 postmortem cases, in: E.B. Clark, A. Takao (Eds.), Developmental Cardiology Morphogenesis and Function, Futura, New York, 1990, pp. 671-727.

[7] E.A. Shinebourne, F.J. Macartney, R.H. Anderson, Sequential chamber localization - logical approach to diagnosis in congenital heart disease, British Heart Journal 38 (1976) 327-340.

[8] S.M. De Tomassi, L. Daliento, S.Y. Ho, et al., Analysis of atrioventricular junction, ventricular mass, and ventriculoarterial junction in 43 specimens with atrial isomerism, British Heart Journal 45 (1981) 237-247.

[9] H. Uemura, S.Y. Ho, W.A. Devine, R.H. Anderson, Analysis of visceral heterotaxy according to splenic status, appendage morphology, or both, American Journal of Cardiology 76 (1995) 846-849.

[10] H. Uemura, S.Y. Ho, W.A. Devine, et al., Atrial appendages and venoatrial connections in hearts from patients with visceral heterotaxy, Annals of Thoracic Surgery 60 (1995) 561-569.

[11] H. Uemura, S.Y. Ho, R.H. Anderson, T. Yagihara, Ventricular morphology and coronary arterial anatomy in hearts with isomeric atrial appendages, Annals of Thoracic Surgery 67 (1999) 1403-1411.

[12] J.P. Jacobs, R.H. Anderson, P.M. Weinberg, et al., The nomenclature, definition and classification of cardiac structures in the setting of heterotaxy, Cardiology in the Young 17 (suppl 2) (2007) 1-28.

[13] J.H. Lin, C.I. Chang, J.K. Wang, et al., Intrauterine diagnosis of heterotaxy syndrome, American Heart Journal 143 (2002) 1002-1008.

[14] M.S. Cohen, Clarifying anatomical complexity: diagnosing heterotaxy syndrome in the fetus, Progress in Pediatric Cardiology 22 (2006) 61-70.

[15] R.H. Anderson, How should we optimally describe complex congenitally malformed hearts?, Annals of Thoracic Surgery 62 (1996) 710-716.

[16] C. Schiffer, G. Tariverdian, M. Schiesser, et al., Agnathia-otocephaly complex: report of three cases with involvement of two different Carnegie stages, American Journal of Medical Genetics 112 (2002) 203-208.

[17] L. Zhu, M.J. Marvin, A. Gardiner, et al., Cerberus regulates left-right asymmetry of the embryonic head and heart, Current Biology 9 (1999) 931-938.

[18] R.V. Pearse, K.J. Vogan, C.J. Tabin, Ptc1 and Ptc2 transcripts provide distinct readouts of hedgehog signaling activity during chick embryogenesis, Developmental Biology 239 (2001) 15-29. 
[19] R.H. Anderson, H. Uemura, S.Y. Ho, et al., Asplenia syndrome, American Journal of Cardiology 74 (10) (1994) 1079.

[20] U. Bartram, J. Wirbelauer, C.P. Speer, et al., Heterotaxy syndrome - asplenia and polysplenia as indicators of visceral malposition and complex congenital heart disease, Biology of the Neonate 88 (2005) 278-290.

[21] L.H.S. Van Mierop, I.H. Gessner, G.L. Schiebler, Asplenia and polysplenia syndromes, in: Bergsma (Ed.), Birth Defects, Original Articles Series, Williams and Wilkins, Baltimore, 1972, pp. 72-84.

[22] H. Uemura, S.Y. Ho, W.A. Devine, et al., Atrial appendages and venoatrial connections in hearts from patients with visceral heterotaxy, Annals of Thoracic Surgery 60 (1995) 561-569.

[23] S. Meryl, M. Cohen, Clarifying anatomical complexity: diagnosing heterotaxy syndrome in the fetus, Progress in Pediatric Cardiology 22 (2006) 61-70.

[24] S. Swaminathan, A. Parthiban, et al., Progressive fetal atrioventricular block in heterotaxy syndrome, Cardiology in the Young 17 (2007) 432-434.

[25] M. Taketazu, J. Lougheed, S.J. Yoo, et al., Spectrum of cardiovascular disease, accuracy of diagnosis and outcome in fetal heterotaxy syndrome, American Journal of Cardiology 97 (2006) 720-724.
[26] E. Goldmuntz, R. Bamford, J.D. Karkera, et al., CFC1 mutations in patients with transposition of the great arteries and double-outlet right ventricle, American Journal of Human Genetics 70 (2002) 776-780.

[27] A.E. Urban, R.H. Anderson, J. Stark, et al., Double-outlet left ventricle associated with situs inversus and atrioventricular concordance, American Heart Journal 95 (1) (1977) 91-95.

[28] J.W. Belmont, B. Mohapatra, J.A. Towbin, S.M. Ware, et al., Molecular genetics of heterotaxy syndromes, Current Opinion in Cardiology 19 (2004) 216-220.

[29] B.D. Gelb, et al., Genetic basis of congenital heart disease, Current Opinion in Cardiology 19 (2004) 110-115.

[30] E. Goldmuntz, B.J. Clark, L.E. Mitchell, et al., Frequency of 22q11 deletions in patients with conotruncal defects, Journal of the American College of Cardiology 32 (1998) 492-498.

[31] M.E. Pierpont, C.T. Basson, D.W. Benson Jr, et al., Genetic basis for congenital heart defects: current knowledge, Circulation 115 (2007) 3015-3038.

[32] M.E. Pierpont, et al., Genetic etiology of cardiac syndromes, Progress in Pediatric Cardiology 6 (1996) 29-41. 